\title{
Mengintip dasar pengembangan sistem informasi dengan metode Agile. Why Agile Rocks?
}

\author{
Hari Mantik \\ hari.mantik@yahoo.com
}

\begin{abstract}
Abstrak
Tulisan ini memberikan ulasan dan wacana singkat mengenai Agile Methodology, termasuk definsi, keunggulan, dan perbedaannya dengan Waterfall Methodology. Menjamurnya perusahaan startup bukan hanya membuat agile semakin dinikmati dan semakin dipilih, tapi juga memberi pertanyaan, mengapa harus Agile? Agile merupakan jawaban akan respons cepat terhadap perubahan, dan mementingkan kolaborasi diatas yang lainnya. Beberapa kelemahan yang didapat ketika sistem dijalankan dengan metode waterfall, seperti kurang fleksibel, dan unpredictable, secara baik dapat ditutupi oleh Agile. Agile menggunakan framework yang disebut dengan "scrum", yaitu sebuah kerangka kerja berbasis manajemen proyek yang menekankan pada kerja tim, akuntabilitas, dan iteratif. Scrum dimulai dengan kick-off meeting, daily stand-up, project backlog, user story, dan sprint. Agile juga menggunakan metode "kanban" yang semakin membuat kerja user semakin cepat, terdedikasi, dan terarah.
\end{abstract}

\section{Pendahuluan Agile Goals}

Tujuan dari agile, atau sering di sebut sebagai "agile manifesto", menyatakan beberapa nilai, diantaranya:

1. Menciptakan interakasi manusia melaului proses dan tools

2. Bekerjanya sistem/software melalui dokumen yang komprehensif

3. Kolaborasi pelanggan

4. Respons terhadap perubahan

Dalam Agile, kita sadar bahwa suatu project melekat suatu ketidakpastian. Keadaan ini memaksa suatu project harus berubah setiap saat. Baik itu perubahan pasar, perubahan regulasi atau perubahan fitur ketika produk mulai "go-live". Agile berhasil merangkul ketidakpastian ini dengan baik. Dengan memecah project kedalam potongan kecil, Agile membuatnya menjadi lebih mudah dalam melakukan prioritas dan menambah atau mengurangi fitur walaupun project sudah mencapai separuh jalan. Ini adalah sesuatu yang sangat tidak mungkin kita lihat di project yang menggunakan metodologi tradisional waterfall.

\section{Prinsip Agile}

1. Prioritas utama Agile adalah memuaskan pelanggan melalui hasil yang lebih awal dan berkelanjutan dalam menciptakan perangkat lunak yang berkualitas

2. Menghasilan (deliver) sistem secara berkala, baik dalam hitungan minggu aatau bulan, dengan preferensi ke skala waktu yang lebih pendek

3. Terbuka terhadap perubahan requirement, bahkan ketika para programmer agile dalam fase kerja yang terlambat. Proses ini dimanfaatkan agile team sebagai keunggulan kompetitif yang mereka tawarkan kepada pelanggan.

4. Tim bisnis dan tim developer harus bekerjasama setiap hari selama project berlangsung demi menghasilkan 
sistem dengan kualitas mutu yang baik.

5. Agile membangun project ditengahtengah kelompok kerja yang sudah termotivasi. Project Manager Agile memberikan ruang dan lingkungan kerja yang kondusif, dengan kata kunci kepercayaan terhadap team dalam bekerja dan berimprovisasi.

6. Agile menggunakan metode yang efisien dan efektif penyampaian informasi kepada team development melalui percakapan tatap muka (faceto-face conversation).

7. Alat ukur utama dalam melihat kemajuan yang terjadi adalah dengan melihat atau membandingkan dengan sistem yang berjalan saat ini.

8. Proses dalam Agile menciptakan pengembangan yang berkelanjutan. Para sponsor, pengembang, dan pengguna harus saling bekerjasama mempertahankan program yang cepat dan berkelanjutan tanpa batas ini secara konstan.

9. Perhatian secara terus menerus pada keunggulan teknis dan desain yang mumpuni adalah bagian dari metodologi Agile.

10. Kesederhanaan seni memaksimalkan penggunaan sumber daya yang efisien (mengurangi jumlah pekerja yang idle) adalah penting.

11. Arsitektur terbaik, requirement yang optimal, serta desain timbul dari örganisasi yang disebut dengan "selforganizing team".

12. Team Agile akan selalu melakukan pekerjaan secara efektif, selalu beradaptasi, menyesuaikan, dan "fine-tuning" menyesuaikan dengan perilaku mereka.
Mengapa Agile diminati? - Why Agile Rocks?

Kalimat "why agile rocks" menjadi fenomena tersendiri. Perusahaan startup yang biasanya berisikan anak muda sangat kondusif terhadap metodologi Agile. Mereka berusia dibawah 30, ambisius, semangat, bekerja dengan kebebasan yang bertanggungjawab, dan situasi kerja yang sangat nyaman. Berikut adalah beberapa karakteristik, mengapa "Agile Rocks"

1. Speed to Market, Agile memungkinkan Project Manager mendapatkan konsep dari user secara cepat. Dalam setiap "sprint" project Agile akan memberikan satu hasil yang bernilai. Di titik manapun, kita dapat menentukan apakah kita akan meluncurkan/deploy apa yang sudah diselesaikan, menguji nya, atau memulai siklus baru pengembangan sistem.

2. Flexibility, Agile tercipta untuk mengakomodir perubahan. Proyek sistem informasi secara konstan mengalami perubahan. Seiring dengan sebuah produk menjadi "life" atau pasar mulai mengalami pergeseran dan perubahan. Dari sini Agile sadar bahwa ide-ide hebat akan datang tiba-tiba disaat project sedang berjalan, dan kita harus memanfaatkanya, bukan mengunci ide tersebut.

3. Risk Management, Agile menggunakan "incremental releases" atau sistem di keluarkan secara bertahap. Artinya produk dapat digunakan di awal-awal proses oleh user atau para stakeholders. Hal ini memungkinkan pengguna dalam mengidentifikasi isu-isu yang timbul lebih awal dan mengenal fitur atau fungsi yang mana yang perlu di tambah. Dengan beradaptasi untuk berubah, bukanlah sesuatu yang tidak mungkin jika ada perubahan scope dan fitur yang 
terjadi ditengah-tengah project. Sesuatu yang tidak mungkin dilakukan dengan metode waterfall.

4. Cost Control, Tidak seperti proyek dengan anggaran tetap (fixed budget), Agile sangat fleksibel dalam menata anggaran sesuai dengan scope yang diminati. Sering terjadi client dan user menyadari jika fitur yang mereka minta di awal ternyata saat ini tidak diperlukan. Hal ini membuat sistem di luncurkan lebih cepat dan client membayar dan membayar lebih sedikit. Agile bukanlah sesuatu yang harus dibayar mahal akan tetapi penuh dengan ketidakpastian. Client hanya membayar untuk sesuatu yang mereka perlukan. Agile mampu melakukan pengaturan ulang backlog produk pada sistem sesuai fitur yang akan di implementasikan, mengorbankan fitur yang tidak penting, sesuai dengan anggaran dari client.

5. Quality, Agile mengintegrasikan pengujian di seluruh proses. Secara konsisten memberikan sistem yang sudah melalui tahap Quality Assurance berarti adalah jaminan suatu produk dengan kualitas yang baik

6. Right Product, Perilisan produk secara inkremental memungkinkan team Agile melakukan pengujian lebih dini dan lebih sering. Bahkan, jika tidak di rilis ke publik pun, akan jauh lebih mudah untuk menemukan berbagai kekurangan dan hal-hal yang dapat di tingkatkan ketika kita mempunyai produk yang jadi yang siap menjadi ajang "play around" para developer dan user.

7. Transparency, Agile memungkinkan kita melihat, merasakan, dan menggunakan proyek secara konsisten di seluruh proyek tanpa adanya pengkotak-kotakan (contoh transparansi menggunakan kanban window dari Jira software)

8. Responding to Change, Selama proses kolaboratif dengan pelanggan, kebutuhan dan prioritas bisnis dapat bergeser dengan cepat. Agile lebih responsif dalam menerima perubahan dibandingkan waterfall, dikarenakan pengembangan software sejak awal terbagi dalam "scrum".

\section{Kesalahpahaman dalam memahami AGILE}

1. It's defferent - Perlu diakui, waterfall model bukankah proses yang sempurna. Walaupun dengan metode waterfall semuanya terasa lebih terkendali karena tahapan dipetakan dari awal, akan tetapi proyek memakan waktu lebih lama dan biaya yang lebih besar. Model waterfall juga tidak secara fleksibel memberi ruang perubahan sebelum suatu project dianggap selesai dan go-live.

2. Fixed budget - Agile memberikan sumber daya yang terdedikasi. Artinya, team Agile dapat memperkirakan berapa lama harus menyelesaikan tujuan yang sudah di gariskan sesuai dengan dana yang dimiliki. Seiring dengan project yang bisa setiap saat berkembang, penambahan fitur baru, dengan metode Agile, kita dapat membuang fitur yang mungkin sudah usang atau tidak cocok, dan menggantinya dengan yang baru, yang lebih murah, dan sesuai dengan dana yang dialokasikan.

3. It's unpredictable - Agile tidak bisa di prediksi. Semua project pun sebenarnya tidak bisa diprediksi. Memang sangat mustahil untuk mengetahui apa yang diinginkan oleh end-user, akan tetapi Agile merangkul ketidakpastian ini dan meman- 
faatkannya untuk menghasilkan yang lebih baik.

4. Developers make all the features Kesalahpahaman yang sering timbul adalah bahwa para pengembang bisa memilih apa yang penting dan apa yang akan diimplementasikan. Hal ini adalah salah. Sebelum "sprint" dimulai, selalu ada rapat komprehensif yang kunci nya adalah: semua pemangku kepentingan harus hadir. Para pemangku itu mencakup pengembang, desainer, team business, serta siapa saja yang terlibat dalam produk. Jadi pengembang bukanlah penentu utama dari metodelogi Agile ini.

5. It doesn't consider long-term Banyak orang beranggapan karena Agile menerapkan release yang bersifat pendek dan berulang-ulang (short-iterative releases), Agile tidak memperhitungkan kebutuhan dan tujuan jangka panjang. Padahal, rilis yang bersifat pendek dan berulangulang adalah cara berbeda dari Agile untuk sampai ke ujung/tujuan. Dengan melakukan sesuatu yang bisa kita uji sejak awal, dengan cara membagi/memecah melalui shortiterative releases, akan lebih memungkinkan kita membuat keputusan dan hasil jangka panjang yang lebih baik.

\section{Agile Lifecycle}

Dalam Agile, siklus hidup yang singkat dalam pengembangan aplikasi berfokus pada "scrum". Proyek scrum ini dipecah menjadi iterasi pendek yang disebut dengan "sprint". Siklus setiap sprint meliputi seperti gambar di bawah ini:

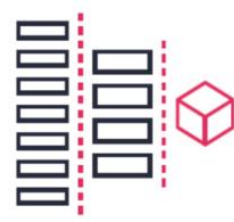

1. PLANNING

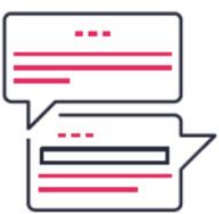

3. REVIEW

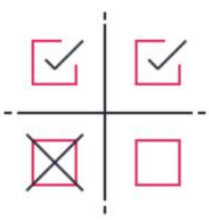

2. EXECUTION

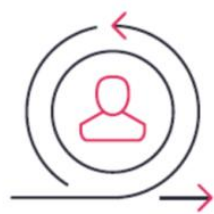

4. RINSE \& REPEAT

Gambar 1: Siklus Sprint (Emerson Taymor, agilehandbook.com)

\section{Kickoff / Sprint Planning}

Setiap scrum-project dimulai dengan kick-off meeting (pertemuan inisialisasi pertama). Pertemuan pertama umumnya membahas kebutuhan project backlog yang harus dibuat, dan memperkenalkan team project. Tujuan awal dari Sprint Planning adalah:

1. Membuat overview / rangkuman dari project dan tujuan yang akan dicapai

2. Menyeleksi dan menetapkan siapa saja yang akan bekerja dalam project

3. Menetapkan PIC dari client yang akan melakukan sign-off (penandatanganan berita acara hasil project)

4. Membuat project-backlog

5. Menetapkan fitur atau fungsi mana yang akan dikerjakan dalam suatu sistem

6. "Getting on the same page" atau seluruh team dan client harus punya paradigma, pandangan dan arah yang sama.

\section{Project Backlog}

Project Backlog merupakan serangkaian daftar fitur produk yang secara umum di definisikan sebagai "user stories". User story dalam Agile diartikan sebagai bahasa yang natural, informal yang 
menjelaskan deskripsi dari satu fitur atau lebih dalam pengembangan sistem. Struktur penulisan user story adalah sebagai berikut:

\section{AS A [type of user], \\ I WANT TO [do this thing], \\ SO THAT I CAN [accomplish this goal].}

Gambar 2: Penulisan user story (Emerson Taymor, agilehandbook.com)

Penulisan User Story memang tidak perlu seperti format diatas. User story juga tidak mewakili requirement dari sistem, tapi dapat memaksa si penulis memberikan "artikulasi" dari 3 pertanyaan berikut:

1. Untuk siapa sistem kita bangun, siapa user kita? - As a <type of user>

2. Apa yang akan kita bangun, apa tujuan sistem ini? - I want <some goal or objective>

3. Kenapa kita membangunnya, value apa yang kita berikan ke user? - So that <benefit, value>

Contoh penulisan User Sory:

"As a visitor I want to search by keyword, so that I can find and read relevant article"

"Sebagai nasabah Bank, saya ingin mengganti PIN secara online, sehingga saya tidak perlu datang ke cabang"

\section{The Sprint}

Project berbasis Agile dipecah-pecah menjadi kecil, dengan interval waktu yang konsisten. Interval ini disebut dengan "sprint". Sprint bisa singkat dalam hitungan beberapa hari, dan umumnya tidak lebih dari 3 sampai 4 minggu. Sebelum setiap Sprint, akan ada "sprint planning meeting", yaitu pertemuan untuk menentukan tujuan dan mekanisme dari sprint. Selama sprint, tidak boleh ada fitur yang ditambahkan, dan sasaran dari sprint tidak boleh di rubah. Satu-satunya pengecualian adalah jika team menyelesaikan 1 sprint lebih awal. Komunikasi dengan klien atau team pengembang umumnya terbatas pada hasil stand-up harian, tetapi beberapa perusahaan memungkinkan dialog terbuka melalui fasilitas chatroom.

\section{Daily Standup}

Salah satu kebiasaan dan menjadi keunikan dari Agile adalah adanya "daily standup" yang dilakukan setiap hari selama project berjalan. Daily Standup wajib dihadiri oleh seluruh team yang terkait. Mulai dari Project Manager, Product Owner, Developer, Tester, dan User. Pertemuan dilaksanakan secara singkat (berkisar maksimum 15 menit), dan kadang disiapkan alarm atau pengatur waktu agar pertemuan tidak terlalu lama dan menghilangkan pembicaraan yang bertele-tele. Sesuai dengan namanya, daily standup, semua orang yang terlibat harus berdiri agar lebih terfokus dan penuh konsentrasi. Jika Project terbagi dalam beberapa sprint dengan jadwal yang sama, berarti juga daily standup dilakukan secara bersamaan dari tiap sprint. Dalam daily standup, tiap orang dalam team harus menjawab 3 pertanyaan sederhana:

1. What did you do yesterday? - Apa yang telah anda capai kemarin?

2. What are you going to do today? Apa yang ingin anda capai hari ini?

3. Do you need any help or there are any blockers in the way? - Apakah anda perlu bantuan, atau ada sesuatu pekerjaan yang tidak bisa dilakukan?

Ketiga pertanyaan tersebut merupakan jembatan menuju transparansi. Semua orang di tim berada dalam keterkaitan (in 
the loop), jawaban yang diberikan akan membuat orang tersebut bertanggungjawab terhadap apa yang mereka katakan dan apa yang akan mereka hasilkan (deliverable). Hasil dari daily standup ini biasanya di bagikan ke client. Komunikasi harian ini memastikan bahwa jika ada yang menahan team, mereka bisa mendapat respon yang cepat.

\section{Jalan Menuju Sukses}

1. Communication. Setiap project mendapatkan manfaat tersendiri dari komunikasi yang baik. Tidak terkecuali project Agile. Jika anda tidak pernah menjalankan project berdasarkan metodologi Agile, komunikasi adalah bagian yang penting dalam Agile. Berada dalam lingkaran project dengan menatap jadwal (yang terlambat, on progress, ataupun apa yang di depan) pasti akan menimbulkan kekhawatiran dan ketidakpastian dalam benak seluruh pihak. Proses yang transparan dan komunikasi yang baik akan membuat team lebih merasa nyaman dan memungkinkan mereka fokus pada yang lebih penting: "memberikan produk terbaik kepada user"

2. Dedicated Team. Agile bekerja paling baik dalam team yang berdedikasi, berisikan orang-orang yang mau dan ingin berkolaborasi. Semakin baik kolaborasi, semakin baik produk.

3. Good Planning. Agar project Agile berhasil, sangat dibutuhkan perencanaan yang baik. Hal ini bukan berarti merencanakan segalanya hingga sedetail mungkin seperti dalam metode waterfall, tetapi dengan berpikir kedepan: "muncul dengan project backlog yang kuat dan mengestimasi fitur sebaik mungkin"

\section{Metode Kanban}

Metode kanban merupakan "lean methodology", atau metode dengan pendekatan sistematis yang menggambar-kan nilai bisnis melalui peningkatan secara terus menerus. Team Agile menggunakan "papan kanban" papan tulis, papan elektronik, bahkan jendela yang dicoretcoret atau ditempel dengan carikan kertas ataupun post-it-notes, untuk menampikan yang kita sebut sebagai kanban (tahapan dan status pekerjaan) yang disusun dalam kolom yang mewakili tahapan daam proses, buffer, kondisi dan antrian. Papan kanban bisa di lihat seperti gambar berikut:

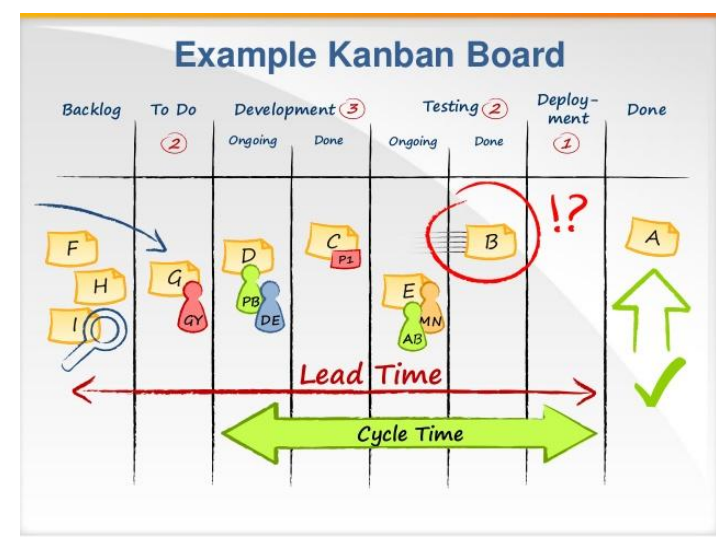

Gambar 2: Kanban Board (https://blog.pinkelephant.com/blog/pr 7 1___using_kanban_for_itsm_operations)

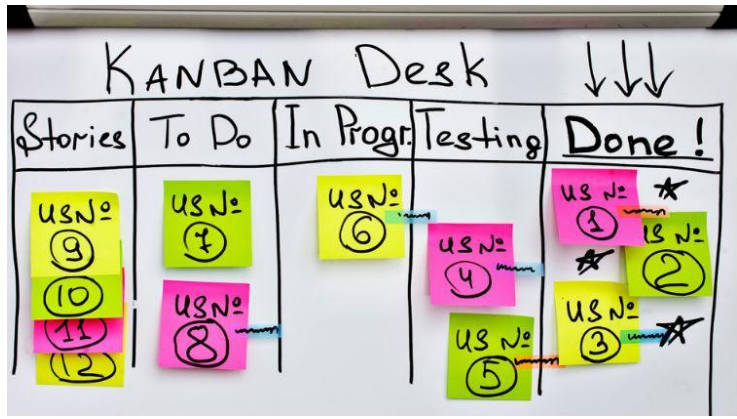

Gambar 3: Kanban Desk

(https://bbvaopen4u.com/en/actualidad/ka nban-method-why-does-it-worksoftware-programming) 


\section{Agile dan Start-Up Company}

Beberapa tahun belakang ini terdapat istilah yang marak dibidang kewirausahaan teknologi informasi yaitu Start-Up. Definisi dari Start-Up adalah fresh, new, innovative companies trying to do cool stuff with technology. Startup merupakan perusahaan baru yang bergerak di bidang teknologi informasi yang mengusung ide baru sebagai model bisnis mereka, startup merupakan bentuk kewirausahaan yang memfokuskan untuk bergerak pada bidang teknologi informasi. Banyak perusahaan besar yang memulai bisnis nya dari perusahaan startup. Beberapa perusahaan startup bahkan saat ini sukses masuk ke lantai bursa di amerika, misalnya Evernote, Yelp, Boxvideo, dan Brightroll. Di jakarta kita mengenal Tokopedia yang sudah memasuki usia 10 tahun dan terus berkembang. Di Bali juga ada Bulseye Digital sebuah perusahaan layanan web yang mempunyai client besar seperti Coca Cola Company dan Ogilvy Australia.

\section{Kesimpulan}

Pilihan metodologi dalam perancangan sistem informasi kini tidak lagi terpaku pada konsep air terjun. Agile membawa perubahan yang cukup besar dalam perjalanan perancangan sistem informasi: lebih cepat, lebih dekat dengan user, lebih kolaboratif, dan lebih terbuka untuk perubahan. Akan tetapi konsep air terjun tidak serta-merta kita tinggalkan. Bagi perusahaan yang bergerak dalam institusi keuangan, perbankan, dan pemerintahan, konsep air terjun masih sangat signifikan dan penting untuk diterapkan. Regulasi pemerintah, security pada kerahasiaan pelanggan, sertifikasi keamanan, seperti PCI DSS (payment card industri data security standard), dan $2^{\text {nd }}$ Authentication token, masih membuat konsep waterfall yang masih menerapkan cara tradisional dalam mendalami keinginan pelanggan (business requirement documents) hingga security awareness tetap menjadi favorit dalam dunia sistem informasi. Baik Agile ataupun konsep air terjun, keduanya adalah konsep terbaik saat ini, tergantung siapa anda, apa business anda, dan siapa client anda.

\section{Daftar pustaka dan bacaan}

Pengembangan Siatem Informasi menggunakan Metodologi Agile, Raharjana, Indra Kharisma, Penerbit Deepublish, 2017

Agile for dummies, Ambler, Scott W., Holitza, Matthew, Wiley, 2012

Agile handbook, Taymor, Emerson, agilehandbook.com/agilehandbook.pdf, 2018

User Story, unknown, https://en.wikipedia.org/wiki/User story, 2018

User Story, unknown, http://www.yodiz.com/blog/writing -user-stories-examples-andtemplates-in-agile-methodologies/, 2018

Metode Kanban, https://bbvaopen4u.com/en/actualid ad/kanban-method-why-does-itwork-software-programming, 2018

Metode Kanban, https://blog.pinkelephant.com/blog/ pr 71__using_kanban_for_itsm_operation s, 2018 